\title{
5 Developing and Implementing Policy Internationally
}

In this chapter a range of the key players in the development of inclusive education at an international level are introduced, and their roles and perspectives are examined. Important here is the growing role of disabled people and their representative organisations. The International Disability Alliance and the Disability Rights Fund are very important. The new United Nations Multi-Donor Trust Fund, which will commence in early 2012, should give a real boost to capacity-building projects and the involvement of disabled people in implementing the UNCRPD.

\section{The Committee on the Rights of Persons with Disabilities ${ }^{92}$}

The Committee on the Rights of Persons with Disabilities is a body of independent experts which monitors implementation of the UNCRPD by the states parties. All states parties are obliged to submit regular reports to the committee on how the rights are being implemented. States must report initially within two years of accepting the Convention and thereafter every four years. The committee examines each report and makes the suggestions and general recommendations that it considers appropriate, and then forwards these to the state party concerned.

The Optional Protocol to the Convention gives the committee competence to examine individual complaints about alleged violations of the Convention by states parties to the Protocol. The committee meets in Geneva and normally holds two sessions a year. It comprises international experts with direct experience of disability, who are independent of government. At the Conference of States Parties held in New York in September 2010, 12 new members were elected, bringing membership up to 18; all except three of these are disabled people. There are currently members from Australia (Chair), Qatar, Jordan, Bangladesh, Chile, Germany, Hungary, Algeria, Republic of Korea, Tunisia, Denmark, Kenya, Spain, Guatemala, Mexico, Serbia, Ecuador and China. ${ }^{93}$

The Committee has had six meetings to date. It has developed rules of procedure which include how agendas are developed, reports from states parties and how complaints and investigations under the Optional Protocol are addressed. The Committee also has the power to call general days of discussion. So far accessibility ${ }^{94}$ and the implementation of Article 12 on the right to equal recognition before the law ${ }^{95}$ have been covered. International NGOs, DPOs, national human rights and disability organisations, and individual experts can contribute to these discussions and a statement is then issued. The Committee has also produced useful guidance to states parties on the submission of treaty-relevant documents. The initial report made two years after ratification should consist of a common core and a treaty-specific document.

The common core document ${ }^{96}$ contains general information about the reporting state, the general framework for the protection and promotion of human rights, disaggregated according to sex, age, main population groups and disability, and information on non-discrimination, equality and effective remedies, in accordance with the harmonised guidelines.

The treaty-specific document submitted to the Committee must not repeat the information included in the common core document or merely list or describe the legislation adopted by the state party (Article 3.1). Rather, it should contain specific 


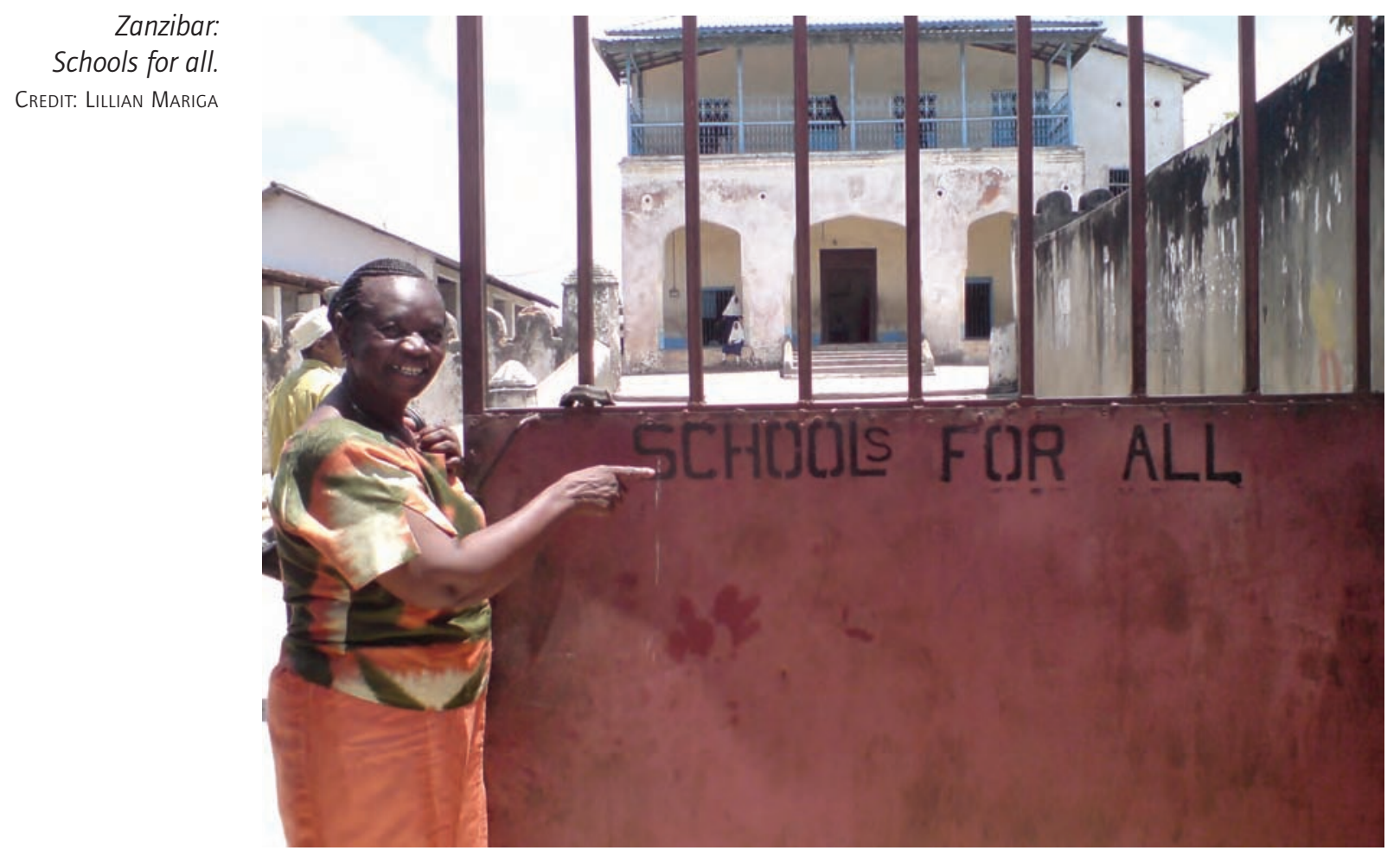

information relating to the implementation, in law and in fact, of Articles 1-33 of the Convention, taking into account analytical information on recent developments in law and practice affecting the full realisation of the rights recognised in the Convention by all persons, with all forms of disabilities within the territory or jurisdiction of the state party. It should also contain detailed information on substantive measures taken towards the Convention's goals and the resulting progress achieved. Where applicable, this information should be presented in relation to policy and legislation applicable to persons without disabilities. In all cases, it should indicate data sources.

In relation to the rights recognised in the Convention, the treaty-specific document should indicate (Article 3.2):

(a) Whether the State Party has adopted policies, strategies and a national legal framework for the implementation of each Convention right, identifying the resources available for that purpose and the most cost-effective ways of using such resources;

(b) Whether the State Party has adopted comprehensive disability anti-discrimination legislation to put into effect provisions of the Convention in this regard;

(c) Any mechanisms in place to monitor progress towards the full realisation of the Convention rights, including recognition of indicators and related national benchmarks in relation to each Convention right;

(d) Mechanisms in place to ensure that a State Party's obligations under the Convention are fully integrated in its actions as a member of international organisations;

(e) The incorporation and direct applicability of each Convention right in the domestic legal order, with reference to specific examples of relevant legal cases; 
(f) The judicial and other appropriate remedies in place enabling victims to obtain redress in the case their Convention rights have been violated;

(g) Structural or other significant obstacles arising from factors beyond the State Party's control which impede the full realisation of the Convention rights, including details of the steps being taken to overcome them;

(h) Statistical data on the realisation of each Convention right, disaggregated by sex, age, type of disability (physical, sensory, intellectual and mental), ethnic origin, urban/rural population and other relevant categories, on an annual comparative basis over the past four years.

The treaty-specific document is limited to 60 pages and should contain specific information on the implementation in law and in practice of the articles of the UNCRPD. The report should provide detailed information on substantive measures taken and progress achieved and an article by article analysis of the UNCRPD in accordance with the reporting guidelines. In October 2009, the CRPD Committee adopted treatyspecific guidelines for reporting. ${ }^{97}$ DPOs must be consulted on the report, but should not write it. There are compelling reasons for maintaining independence from the state.

There is provision for civil society - 'the arena outside the family, state and the market, which is created by individual and collective actions, organisations and institutions to advanced shared interests' ${ }^{\prime 98}$ - to make its own report to the Committee.

This includes a provision enabling DPOs to submit an independent report that evaluates the position of disabled people in their country.

Guidance on monitoring the implementation of the UNCRPD states:

One of the principle functions of the Committee on the Rights of Persons with Disabilities is to review periodic reports submitted by States parties under Article 35 of the CRPD. The Committee prepares for its dialogue with the State Party by requesting additional information in the form of a list of issues. The State Party report and the responses to the list of issues form the basis of the discussion with the State Party. Following the dialogue, the Committee issues concluding observations, which highlight key issues of concern and make recommendations for follow-up actions.

DPOs have the opportunity to provide input on how the CRPD is being implemented at national level at various stages including during the drafting of the State Party report, the list of issues and the concluding observations. DPOs also have a role to play in the follow-up to the concluding observations, during days of general discussion and in the drafting of general comments. Involvement and participation with national monitoring frameworks and other national implementation and monitoring bodies is a key component to ensuring the effective implementation of the CRPD. ${ }^{99}$

There is also a facility for civil society organisations and others to address the Committee when it is considering their country's reports. This process is called 'shadow or parallel reporting'. Experience from committees set up to monitor other human rights treaties shows that it is far more effective to have one joint report from all parts of civil society. Articles 4 and 32 make it clear this process should be led by DPOs. The IDA provides guidance on shadow reporting. ${ }^{100}$

DPOs are encouraged to prepare parallel reports on the implementation of the CRPD at national level in order for the Committee to effectively monitor the implementation of the CRPD in a country. DPOs are encouraged to establish or strengthen national CRPD coalitions and to produce a parallel report on the basis 
of consultations and input received from members of the coalition. A comprehensive parallel report should cover all the articles of the CRPD, identify gaps, highlight key areas of concern and make concrete recommendations for change. A brief explanation of each article of the CRPD is provided below with a non-exhaustive list of issues that may assist DPOs in identifying gaps in the implementation of the CRPD at national level. Concrete suggestions to ensure the effectiveness of parallel reports are also provided.

To date, the Committee has only reviewed four reports from state parties - those of Spain, Tunisia, Peru and China. Other reports submitted to date are from Argentina, Austria, Hungary, Paraguay, Australia, El Salvador, Costa Rica, Sweden, Azerbaijan, Mexico, Republic of Korea, Belgium, Croatia, Czech Republic, Germany and the UK. As 109 countries and the EU have now ratified the UNCRPD, many more will soon join the queue.

The Committee was allocated an extra week by the General Assembly in 2011 to deal with the reports backlog and to receive written and oral evidence from shadow reports from DPOs and NGOs. The Office of the High Commissioner on Human Rights (OHCHR) supports the Committee and has issued guidelines on monitoring the UNCRPD. ${ }^{101}$

The right to education requires, inter alia, examining whether pupils and students with disabilities are not excluded from the general education system on the basis of their disability, that reasonable accommodation of the pupil's requirements is provided in the general education system and that effective individualised support measures are provided to maximise academic and social development consistent with the goal of inclusion.

The IDA has produced much fuller advice on monitoring and shadow reporting.

\section{International Disability Alliance ${ }^{102}$}

Established in 1999, the International Disability Alliance is a network of global and regional organisations of persons with disabilities that promotes the effective implementation of the UNCRPD. The IDA currently comprises eight global and four regional DPOs; two other regional DPOs have observer status. With member organisations around the world, the IDA represents the estimated one billion people worldwide living with an impairment. This is the world's largest - and most frequently overlooked - minority group. The IDA was instrumental in establishing the International Disability Caucus, the network of global, regional and national organisations of persons with disabilities and allied NGOs, which became a key player in the negotiation of the UNCRPD. The IDA is now a major international player in support of the UNCRPD at international, national and regional levels.

In order to generate a wider coalition to promote the implementation of the UNCRPD, the IDA has established the IDA CRPD Forum, a structure open to any international, national or regional organisation which promotes the UNCRPD and accepts DPO leadership. The IDA governing body is composed of the chairs of all its member organisations. It meets at least twice annually, usually in Geneva or New York. The IDA, with its unique composition as a network of the foremost international disability rights organisations, is the most authoritative representative voice of persons with disabilities and is acknowledged as such by the UN system both in New York and Geneva.

Among other activities, the IDA is the key focal point for the disability rights movement in developing an ongoing relationship between the UN organs and civil society, including the UN Department of Economic and Social Affairs (DESA), the OHCHR, 
the Conference of States Parties, UN Special Procedures and, most recently, the CRPD Committee. The IDA is also committed to building the capacity of national DPOs with special attention to the global South, in order to support national efforts toward ratification, implementation and monitoring of the UNCRPD.

The eight global and four regional organisations of persons with disabilities which are members of the IDA are:

Disabled Peoples' International (DPI) (www.dpi.org) - a network of national organisations or assemblies of disabled people, established to promote the human rights of disabled people through full participation, equalisation of opportunities and development in 140 countries.

Down Syndrome International (DSI) (www.ds-int.org) - an international organisation that promotes the rights of persons with Down syndrome.

Inclusion International (II) (www.inclusion-international.org) - a grassroots organisation of persons with an intellectual disability and their families. With its member societies in over 115 countries, it advocates for the inclusion of people who have an intellectual disability in all aspects of their communities, based on shared values of respect, diversity, human rights, solidarity and inclusion.

International Federation of Hard of Hearing People (IFHOH) (www.ifhoh.org) - an international non-governmental organisation of national associations of and for hard of hearing and late deafened people. IFHOH provides a platform for co-operation and information exchange among its members and interested parties. As an umbrella organisation and through its individual organisations, IFHOH works to promote greater understanding of hearing loss issues and to improve access for hard of hearing people worldwide. It currently has 47 general and associate members in 30 countries.

World Blind Union (WBU) (www.worldblindunion.org) - the sole voice speaking on behalf of approximately 160 million blind and partially sighted persons in 178 individual member countries, representing approximately 600 organisations. The WBU advocates for human rights of persons who are blind and partially sighted and seeks to strengthen their organisations and advance the participation of all persons who are blind and partially sighted, including women and youth.

World Federation of the Deaf (WFD) (www.wfdeaf.org) - an international NGO representing deaf people worldwide. A non-profit organisation, WFD works for human rights and equal opportunities for Deaf people everywhere.

World Federation of the Deafblind (WFDB) (www.wfdb.org) - a non-profit, representative organisation of national organisations or groups of deafblind persons and of deafblind individuals worldwide. The aim of WFDB is to be a forum for the exchange of knowledge and experiences among deafblind persons and to obtain inclusion and full participation of deafblind persons in all areas of society.

World Network of Users and Survivors of Psychiatry (WNUSP) (www.wnusp.net) - a democratic organisation of users and survivors of psychiatry that represents this constituency at the global level. In its statutes, 'users and survivors of psychiatry' are selfdefined as people who have experienced madness and/or mental health problems or who have used or survived mental health services. Founded in 1991, WNUSP currently has members in over 50 countries, spanning every region of the world.

Arab Organization of Disabled People (AODP) - an independent non-profit organisation founded in 1989 in Cairo, Egypt. It is a regional organisation composed of DPOs operating in various Arab countries. AODP's main objectives are to promote the 
rights of disabled people, empower disabled people and represent Arab disabled people in the world at large.

European Disability Forum (EDF) (www.edf-feph.org) - an independent European non-governmental organisation (ENGO) representing the interests of 60 million disabled people in the EU. It was created in 1996 and is based in Brussels.

The Latin American Network of Non-Governmental Organizations of Persons with Disabilities and their Families (RIADIS) (www.riadis.net) - a network formed by organisations of disabled people from 19 countries in Latin America and the Caribbean. Formed in 2002, RIADIS represents more than 60 national organisations, as well as several NGOs acting as technical collaborators.

Pacific Disability Forum (PDF) (www.pacificdisability.org) - the regional response to addressing disability issues in the Pacific. The PDF was established in 2002 and officially inaugurated in 2004 to work towards inclusive, barrier-free, socially just and gender equitable societies that recognise the human rights, citizenship, contribution and potential of disabled people in Pacific island countries and territories.

In its monitoring document, IDA (2010) asks some useful questions about implementation of Article 24. All disabled children and adults have the right to access education on an equal basis with others. This includes all stages and types of education, ranging from pre-school to basic education to university to lifelong learning. Moreover, all persons with disabilities should have the right to access inclusive education with adequate individualised support to enable them to take part. Article 24 pays special attention to the situation of children who are blind, deaf and deafblind.

\section{Questions to be addressed}

- Are there any disabled children who are considered 'ineducable' or who are forced to attend special schools due to the nature and severity of their disability?

- Does the general education law ensure that disabled children can access all stages of mainstream education and receive the support required within the general education system to facilitate their effective education, including reasonable accommodations, when they so require?

- Are any children required to use medication (including psychiatric medication) or undergo any medical treatment as a condition of receiving an education?

- Do blind, deaf and deafblind children have access to education in Braille, sign language and other methods of communication, including augmentative and alternative modes, means and formats of communication?

- Do deaf people have access to quality education in a sign language environment, including teachers who are fluent in sign language and teaching materials which are provided in sign language?

- Does education facilitate the learning of sign language and support the linguistic and cultural identity of deaf people?

- Do states facilitate the learning of Braille, alternative script, augmentative and alternative modes and means of communication, as well as orientation skills?

- Are mainstream teachers provided with adequate support to ensure that disabled children can take part in education on an equal basis with other children?

- Are there any barriers that prevent persons with disabilities from becoming teachers? 


\section{The Commonwealth}

The Commonwealth is a voluntary association of 54 countries that support each other and work together towards shared goals in democracy and development. The world's largest and smallest, richest and poorest countries make up the Commonwealth and are home to two billion citizens of all faiths and ethnicities, over half of whom are 25 years old or under. Member countries span six continents and oceans from Africa (19) to Asia (8), the Americas (2), the Caribbean (12), Europe (3) and the South Pacific (10). Most countries used to be British colonies, but nations join on the basis of free and equal association and support of democratic principles. Recently, Cameroon, Mozambique and Rwanda, who have no past links to British colonialism, joined the association. Beyond ties of history, language and institutions, it is the association's values that unite its members: democracy, freedom, peace, the rule of law and opportunity for all. Ministers of Education meet every three years and the last meeting, held in 2009, focused on inclusive education. As well as the Commonwealth Heads of Government Meeting (CHOGM), which takes place every two years, ministers responsible for education, environment, civil society, finance, foreign affairs, gender affairs, health law, tourism and youth also meet regularly. This ensures that Commonwealth policies and programmes represent the views of the members and gives governments a better understanding of each other's goals in an increasingly globalised world.

The association has three intergovernmental organisations: the Commonwealth Secretariat, which executes plans agreed by Commonwealth Heads of Government through technical assistance, advice and policy development; the Commonwealth Foundation, which helps civil society organisations promote democracy, development and cultural understanding; and the Commonwealth of Learning, which encourages the development and sharing of open learning and distance education.

It has been hard to get the structures of the Commonwealth to acknowledge the role that disabled people's organisations can play in policy and development. The following statement was only included in the 2007 CHOGM Ministerial Statement because of the founding of the Commonwealth Disabled People's Forum ${ }^{103}$ in Uganda in 2007. It has subsequently been poorly supported, but is still functioning.

The Ministerial Statement from CHOGM in 2007 adopted the following as the statement from the Peoples Forum:

64 Emphasising the importance of mainstreaming and recognising disability as an integral part of relevant strategies for sustainable development;

65 We call on Commonwealth Member States to ratify and implement the UN Convention on the Rights of Persons with Disability and its Optional Protocol, and adopt disability inclusive policies. ${ }^{104}$

The Commonwealth should be well-placed to take the development of inclusive education for disabled children and students forward, but there remains a political gap. For example, in the communique issued at the 2009 Conference of Education Ministers in Kuala Lumpur, 'Going Beyond Global Targets', there is no specific mention of disabled children or link to UNCRPD Article 24. The communiqué stated:

Ministers highlighted the need for all children to have equity of access to quality education, regardless of geographical location, resources, gender, ethnicity and ability, in order to equip them to interact effectively in a global community. Ministers committed themselves to working towards this end as a priority, while recognising the need to tailor approaches to take account of socio-economic and cultural diversity across different member countries. ${ }^{105}$ 
The launch of the Commonwealth Disabled People's Forum, March 2008.

CREDIT: Richard RIESER

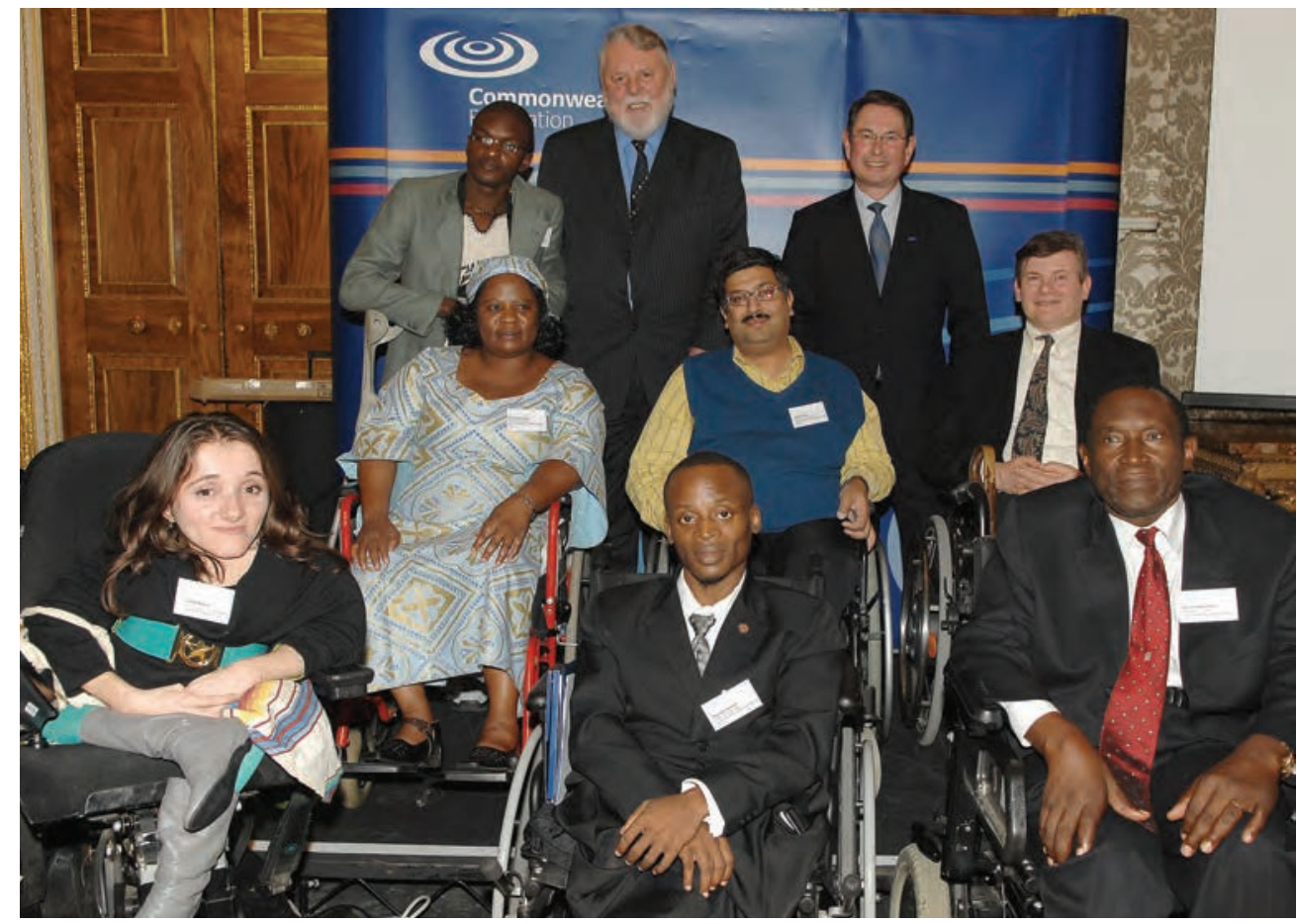

It is true there were some presentations on the position of disabled children in the education system, ${ }^{106}$ but the ideas did not make it into the communique or subsequent policy statements.

This lack of focus perhaps explains why Commonwealth countries are lagging behind in the proportion adopting and ratifying the UNCRPD. In 2011 the Commonwealth Foundation funded a successful capacity-building project for DPOs in the countries of the South Pacific. This was a partnership between the UK Disabled People's Council and the Pacific Disability Forum delivered by World of Inclusion Ltd $^{107}$ and was reported to the UN Conference of States Parties as a model. At the same meeting at the 2011 Conference of States Parties in New York, the Commonwealth Secretariat held a side meeting to publicise two recent publications on Human Rights and the UNCRPD. ${ }^{108}$

\section{Disabled Peoples' International}

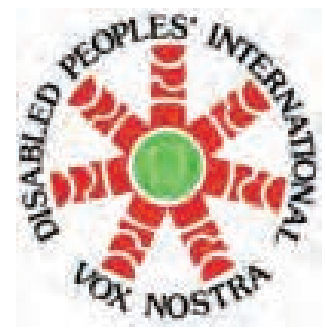

Disabled Peoples' International is a network of national organisations or assemblies of disabled people that promotes the human rights of disabled people through full participation, equalisation of opportunity and development. DPI was set up in 1981. As in rich countries, the experience of social exclusion stimulated a growing radicalisation among disabled people in poor nations.

The conflict between 'old' and 'new' disability politics surfaced at the meeting of Rehabilitation International (RI), an organisation led by non-disabled professionals wedded to traditional 'apolitical' medical interpretations of disability, in Singapore in 1980. Because of their exclusion from Rl's controlling body, dissident disabled delegates left to set up DPI, an international umbrella for national organisations run by disabled people (Driedger, 1989). The formation of DPI 'sent a clear message to bodies such as the $R I$ that never again would it be acceptable for discussions about disabled people to take place without our full and equal participation' (Flood, 2005: 184).

DPI's goals are to promote the human rights of disabled persons; to promote the economic and social integration of disabled persons and to develop and support disabled persons' organisations. According to its constitution: 
Whereas disability has too long been viewed as a problem of the individual and not the relationship between an individual and his/her environment, it is necessary to distinguish between:

(a) Disability (impairment) is the functional limitation within the individual caused by physical, mental, or sensory impairment, and

(b) Handicap (disability) is the loss or limitation of opportunities to take part in the normal life of the community on an equal level with others due to physical or social barriers.

Over 25 years this formulation became the core of the UNCRPD and the shift from (a) to (b) embodies the paradigm shift at the heart of the Convention. The 2005 DPI position paper on inclusive education became the pillar on which Article 24 is based.

DPI is encouraged by the implementation of inclusive education policies in many countries that have resulted in positive changes in the lives of people with disability in those countries.

DPI recognises that if we are to achieve an inclusive society it is imperative that children with disabilities are integrated into their schools at the earliest possible opportunity so that this inclusion can benefit both disabled and non-disabled children ensuring that education for people with disability is:

- Not segregated or in a 'special' school,

- A quality education that recognises the principle of lifelong learning,

- Develops all the talents of each learner to reach their full potential, and

- Accommodates the individual needs of each learner's disability.

DPI believes that education should be accessible to all who desire to be educated, no matter their ability; people with disability should have the option to be integrated with the general school population, rather than being socially and educationally isolated from the mainstream without any choice in the matter. Students who are deaf, blind or deafblind may be educated in their own groups to facilitate their learning, but must be integrated into all aspects of society.

To help ratify and implement the UNCRPD, DPI has produced two useful tool kits: the UN Convention Ratification Kit ${ }^{109}$ and the DPI UN Convention Implementation Kit. ${ }^{110}$

\section{Disability Rights Fund"11}

The UNCRPD places disabled people's representative organisations at the heart of implementing the Convention. The purpose of the Disability Rights Fund (DRF) is to build DPO capacity.

In DRF's understanding of the term, DPOs are representative organisations or groups of people with disabilities in which disabled persons constitute a majority of the staff and board, and are well-represented at all levels of the organisation. In addition, DPOs have an understanding of disability that accords with the social model.

The DRF is a collaboration between donors and the global disability rights movement to increase resources for disabled persons organisations in the global South and eastern Europe. The DRF focuses its grants on building the capacity of DPOs to be full and equal participants in the achievement of rights for the world's one billion people with disabilities. With modest grants, the DRF assists both national and local DPOs 
to work on:

1. Advocacy to promote ratification, implementation and monitoring of the UNCRPD.

2. Proposing legislative amendments in line with the UNCRPD.

3. Raising awareness about the UNCRPD.

4. Promoting DPO involvement in the implementation of the UNCRPD.

5. Increasing skills in addressing the UNCRPD by building more inclusive organisations and building internal capacity.

6. Addressing Implementation of specific UNCRPD Articles.

So far grants ranging from US $\$ 5,000$ to US $\$ 100,000$ have been awarded. A total of US $\$ 5$ million has been awarded to DPOs in Chana, Namibia, Uganda, Bangladesh, India, Indonesia, Ukraine, Ecuador, Mexico, Nicaragua, Peru, Federation of Micronesia, Fiji, Papua New Guinea, Solomon Islands and Tuvalu.

Donors who have joined the pooled fund are: American Jewish World Service, AusAID, the UK Department for International Development, Leir Charitable Foundation, Open Society Institute and Sigrid Rausing Trust.

\section{Department for International Development, UK}

The Department for International Development manages the UK's aid to poor countries. Its work is focused on achieving the Millennium Development Goals.

It works with international organisations, charities and the governments of poor countries to find lasting solutions to the global problem of poverty. ${ }^{112}$

Like some other donors, DFID has provided some support for equality for disabled people in its aid programmes, but until recently it did not try to include the issue in all its programmes. In 2010, 87 per cent of UK official development aid came from DFID. This amounted to $£ 8,243$ million (0.56\% of UK GDP).

Disability, Poverty and Development, a DFID research paper published in 2000, focused on many important points regarding disability and development, such as the adoption of the rights-based approach, with specific focus on social exclusion, the use of the social model and the twin-track approach to disability in development policies. The latter encourages specific and targeted activities to support the empowerment of disabled people and enhance their capacity to claim their rights, and the mainstreaming of disability issues in all areas of work, ensuring that disabled people themselves are consulted about issues that affect them.

However, this twin-track approach was not mandatory. DFID then commissioned a major action research project, Disability, Knowledge and Research (2000-2004), with disabled people firmly in the driving seat. Yeo (2005), analysing the new role of the World Bank in promoting inclusion for disabled people, concludes:

There appears to be a widespread assumption in the disability sector that inclusion is necessarily good, with little assessment of the wider context. If the existing system is the cause of the problem, then inclusion within it cannot be the answer. Wider assessment of the context is urgently required and alliances need to be built between marginalised people, if there is to be any real chance of creating a more humane and just society.113

Illustrative disability programming supported by DFID includes both disabilityspecific initiatives and disability components within the framework of mainstream 
programmes. DFID's 'targeted work on disability' supports DPOs, government partners and other CSOs in influencing disabled people's access to services and assets; the voice and agency of disabled people; the legal and policy framework; and discriminatory attitudes and behaviour. Two examples of this are work with the Southern African Federation of the Disabled (SAFOD) on a four-year research programme and thematic research on education and HIV/AIDS. The objectives of the programme are to build the capacity of DPOs to undertake research and influence policy development. DFID has also contributed to the Government of India's universal primary education programme and the reproductive and child health programme, both of which include disability-specific indicators which enable the government and donors to track progress for disabled people. DFID Malawi supported the Federation of Disability Organizations in Malawi in ensuring that disabled people are included in HIV/AIDS policies and have equal access to information.

Following the UK's adoption of the UNCRPD, a 'country desk note' was produced to try and mainstream disability issues. ${ }^{114}$ However, DFID was still criticised by DPOs and NGOs for failing to ensure that disabled children were made a priority. In 2009, Results UK was commissioned to evaluate the DFID programme for disabled children and education.

... The UK's Department for International Development (DFID) have established a policy environment that supports inclusive education, tackling the issue via two approaches - through 'mainstreaming' disability issues across their work, and through targeted projects that specifically aim at increasing the number of disabled children completing school. However, progress towards these goals is extremely slow, and in many countries almost non-existent. ${ }^{115}$

Results UK carried out research into the implementation of these policies during the summer and autumn of 2009. The research revealed serious concerns about the implementation of DFID's policy on education and disability. Only 11 per cent of respondents to the survey from countries included in DFID's Public Service Agreement (PSA) reported that disabled children were taught within an inclusive system in their countries. Good practice examples within DFID's education portfolio did exist, but there was little evidence of a sustained, consistent response to disability. Overall it was found that neither the 'mainstreaming' nor the 'targeted' side of the twin-track approach was properly implemented. In many cases country offices did not support any targeted programmes for disabled children, while in programmes that ostensibly mainstreamed disability, the level of resources that could be identified as supporting disabled children was worryingly low. For example, it was found that only 3 per cent of DFID India's support for the Sarva Shiksha Abhiyan programme (which aims to increase access to education for the most marginalised groups in Indian society) and only 0.25 per cent of DFID Tanzania's sector budget support was targeted at supporting disabled children.

The research also found that international financing mechanisms for education did not currently pay enough attention to the specific needs of disabled children. Although the EFA FTI has developed an 'inclusion tool' designed to ensure that marginalised groups are properly considered in the drafting of country education plans, this is not widely used. The majority of funding for education in the developing world comes from domestic resources, where disability often remains a neglected consideration. The research found, for example, that many countries did not comprehensively monitor data on disabled children in the education system. It argued that DFID could play a key role here through technical assistance and engagement, but it was appar- 
ent that there was still a severe implementation gap between policy and practice in DFID's work on disability and education.

UK Results made the following recommendations to DFID:

1. As disabled children represent one-third of the world's out-of-school children, there should be a strong focus on disability and breaking down the barriers to learning faced by disabled children across all of DFID's core education work, with specific, targeted interventions progressively put in place.

2. The implementation of DFID's policy on inclusive education and the rights of people with disabilities needs to be far more uniform across the work of the department, but it is not widely applied, including at country level. For this to happen, specific individuals need to be identified in DFID's central and country-level offices to be responsible and accountable for ensuring the needs of people with disabilities are included in DFID's education work.

3. DFID should work much more closely with national Disabled People's Organisations at country office level, with specific named individuals responsible for ensuring that these partnerships are strongly forged.

4. DFID should make a commitment in its forthcoming education strategy to support countries in improving their teacher training systems, including the provision of inservice continuing professional development (CPD). Training supported by DFID should encourage teachers to employ inclusive pedagogic methods that empower them to support disabled children.

5. Policy interactions on education with partner governments and international institutions should routinely include reference to the needs of disabled people, and DFID should encourage and enable partners to address this issue.

6. DFID should advocate for inclusive education and the needs of people with disabilities at key international events such as the High Level Group Meeting on Education for All in Addis Ababa in February 2010, the G8 and G20 summits in Canada and the MDG Review in September.

7. DFID should support and encourage the work underway at the FTI and the UNESCO Institute for Statistics to ensure that national and international monitoring data includes specific indicators to: (a) identify the progress made in ensuring access to high-quality, inclusive education for all children; and (b) report on access to education for marginalised groups including disabled children. DFID should work towards ensuring that this data is collected in the countries in which they work, and use it to review the department's contribution to making education more inclusive and set targets for improvement where gaps are identified.

8. DFID can play an influential role in ensuring that the international financing architecture for education supports inclusive education and the needs of disabled people. Specifically, the department should advocate for the insertion of an indicator on inclusion into the FII Indicative Framework, as well as the use of the FTI 'equity and inclusion framework' to assess all new education sector plans, and should use its influence as a major funder of the World Bank and the European Commission to ensure that their policies align with the Department's own.

9. DFID should work collaboratively at country level with national education coalitions, such as the Global Campaign for Education, to support the development and roll- 
out of inclusive education planning tools and assist CSOs in advocating for sufficient domestic funding for inclusive education.

Since the publication of this highly critical report, DFID has commissioned a guidance note, 'Education for Children with Disabilities: Improving Access and Quality' (DFID, 2010a). This was produced by a contracted agency, Mott MacDonald, and not written by the disability movement. Since 2005 DFID has distanced itself from the disability movement, preferring to work with NGOs who put forward a view that it finds more palatable. Following the UK's adoption of the UNCRPD, the UK Disabled People's Council issued a manifesto, Equalise It, which asserts the primacy of disabled peoples' organisations in determining the goals and monitoring of aid projects (UKDPC, 2007). The manifesto was signed by many of the organisations DFID wants to work with, such as SAFOD, but DFID has not engaged with the manifesto in its dealings with DPOs.

Subsequently, eight UK-based international NGOs wrote to DFID calling on it to:

- ensure that the development and annual review of national education policy effectively address issues of equity and inclusion;

- make a public commitment to inclusive education and further policy dialogue and commitment on inclusive education within the international community, especially the FTI;

- provide financial and lobbying support to ensure that critical knowledge gaps in inclusive education are filled through research initiatives.

In supporting DFID to meet its commitments to the inclusion of disabled children in education, we as civil society organisations can:

- provide DFID with details of DPOs and national federations of disabled people active in countries where DFID is present;

- partner with DFID in delivering on the measures listed in its 'How to Note' on disability through, for example, providing links to potential local partners;

- provide DFID with access to inclusive education programmes run by civil society in PSA countries;

- provide DFID with key resources on inclusive education and CBR;

- provide DFID with good practice examples in inclusive education programming;

- work with DPOs to support their capacity to engage in education policy-making and advocacy;

- mobilise civil society to advocate for strategies to promote inclusive education at national level with both donors and national governments; and

- work with DFID on the development and delivery of research to fill key knowledge gaps. ${ }^{116}$

DFID is a big player on the international scene, but it has not so far pushed for the above objectives and there has been little sign of the hoped for improvements. Disability is still kept in its pigeon hole and neither part of the twin-track approach is mainstreamed. DFID is also a major contributor to the Disability Rights Fund and funds Action on Disability and Development (ADD). 


\section{The policy positions of international donors}

Other international aid donors on education have similar problems, as is apparent from the analysis below carried out by Inclusion International (2009). As the goal of universal primary education is nearly reached, there is a danger that donors who do not have specific disability policies will move on to other priorities and the issue of the inclusion of disabled children will be ignored.

Table 5.1 shows the variability of policy commitment to disabled pupils.

\begin{tabular}{|c|c|c|c|}
\hline Government agency & Disability policy & $\begin{array}{c}\text { Disability in } \\
\text { education policy }\end{array}$ & $\begin{array}{c}\text { Education in } \\
\text { disability policy }\end{array}$ \\
\hline AusAID & $x$ & & $x$ \\
\hline \multicolumn{4}{|l|}{ CIDA } \\
\hline \multicolumn{4}{|l|}{ DANIDA } \\
\hline DFID & $x$ & & \\
\hline European Commission & $x$ & $x$ & $x$ \\
\hline GTZ & $x$ & & $x$ \\
\hline JICA & $x$ & & \\
\hline NORAD ${ }^{117}$ & & $x$ & \\
\hline \multicolumn{4}{|l|}{ NZAID } \\
\hline SIDA & $x$ & $x$ & $x$ \\
\hline USAID & $x$ & & $x$ \\
\hline
\end{tabular}

\section{Education International}

Education International (EI) is a global organisation grouping teachers' unions and organisations all over the world. El speaks up for over 30 million education staff. It supports quality Education for All, and the decent working and teaching conditions for qualified teachers that are essential to achieve that goal. It is supportive of moves to inclusive education, but wants this to be implemented by properly trained teachers, who are decently paid and respected.

El views the privatisation and marketisation of education based on competition as the greatest threat to developing inclusive education around the world.

Gaston De la Haye, El's Deputy General Secretary, made the following point at the closing of the 48th UNESCO International Education Conference in Geneva in November 2008. ${ }^{118}$

$E l$ is supportive of the new concept, this new paradigm of inclusive education because it has developed from the concept of integration to the concept of inclusion. That is a very noble evolution but we need to be vigilant that this noble objective does not rub out differences and lead to assimilation. It is pedagogically a very interesting new concept because it is comprehensive, pursuing horizontal inclusion, (including all children whatever their origin, their differences, wherever they live) and vertical inclusion, in a Life Long Learning (LLL) perspective taking on board Early Childhood Care (ECC), basic education, secondary education, vocational education, higher education and adult education. It is a concept that has a strong link and reference to the Universal Declaration of Human Rights, the Convention on the rights of the child and the convention on the rights of disabled persons. This is important as the concept of inclusive education needs to be carried universally. It is a concept that opens the way for new pedagogical methods that are more multipolar (involving different actors in the classroom: peers, parents, social workers) 
instead of bipolar (teacher-student) ... Inclusive education is also the better way to educate young people about inter-culturalism and tolerance, appreciating diversity and to prepare young people to live positively in a multicultural society. But inclusive education will only be possible if it is supported by an inclusive society and this might be the biggest obstacle to inclusive education.

Inclusive education is an ambitious project in terms of change, in terms of teacher education and thus also in terms of financial resources. Sure some resources can be redirected, but if we want the inclusive project to really create inclusion and not generate greater exclusion, we need to be aware that this will cost money, if it only were because teachers represent on average 70 per cent or more of the education budget. In 2000 the idea of a benchmark of 6 per cent GDP for education was tabled without really being taken up in the Dakar global framework for action. Very few countries reach 6 per cent of GDP for education and OECD studies show that in many countries the percentage of GDP for education is being reduced. It is also necessary to realise that decentralisation aiming at reducing inequalities does in some cases lead to greater inequalities because financial means are not properly distributed and channelled as it appears from the 2009 GMR. The marketing and commercialisation of education, privatisation of or in education are conceptually in opposition with inclusive education. Competition and research for profit will never lead to inclusion ...

Speakers in the workshops at the conference insisted that inclusive education will only be possible with high quality teachers. Recruiting even more unqualified teachers to address the teacher gap would create an immense problem for the future.

They argued that privatisation and competition would destroy team spirit; that teachers needed a high level of initial training and that inclusive education was an opportunity to develop better democratic governance at all levels. The key message of the conference was that good teachers, qualified and motivated, were essential for progress towards inclusive quality education for all.

\section{Enabling Education Network}

The Enabling Education Network (EENET) is an inclusive education informationsharing network, open to all. It helps a wide range of people to access information and encourages critical thinking and innovation on issues of inclusion, equity and rights in education. EENET takes a broad view of inclusive education, focusing on all excluded groups (Stubbs, 2008).

The main feature of its website is an extensive resources database, containing over 400 short articles, longer documents, posters, training manuals, videos and much more from around the world. It also carries information about regional networks on inclusive education. EENET-inspired networks exist in Asia, east African Portuguesespeaking-countries and Zambia. EENET is hosted by the Centre for Educational Support and Inclusion, University of Manchester, UK. The website is growing all the time and has a wide range of articles and tools about inclusive education around the world.

A participatory seminar held in Agra, India, in 1998 defined EENET's concept of inclusive education as follows:

Inclusive education:

- Acknowledges that all children can learn

- Acknowledges and respects differences (age, gender, ethnicity, language, disability and HIV status) 


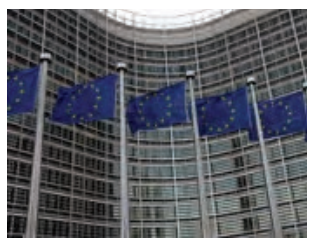

- Enables education structures, systems and methodologies to meet the needs of all children

- Is part of a wider strategy to promote an inclusive society

- Is a dynamic process which is constantly evolving

- Need not be restricted by large class sizes or shortage of material resources

\section{European Union}

The European Union, together with its member states, is the largest provider of development assistance. The legal parameters for European development co-operation are set out in a variety of legal instruments, including the Amsterdam Treaty. The touchstone for European development co-operation is poverty reduction as expressed in the MDGs. In 2004, the European Commission issued a Guidance Note on Disability and Development (European Commission, 2004). This document provides advice to EU delegations on how to address disability within the context of development cooperation and explicitly recognises that poverty reduction goals 'cannot be met without considering the needs of disabled people' and, further, that 'disabled people are still not sufficiently included in international development work funded by the EU'.

The Guidance Note articulates ten core principles intended to serve as a guide to European delegations and services, including: (1) understand the scale and impact of disability in the country setting and recognise the diversity of the population of persons with disabilities; (2) advocate and support the human rights model of disability rather than the charitable or medical approach; (3) pursue a 'twin-track approach', defined as the need to 'mainstream disability issues across all relevant programmes and projects and to have specific projects for disabled people'; (4) assess the extent to which country programmes are inclusive of persons with disabilities. In 2000-2009 280 projects specifically addressed disability, targeting people with both mental and physical disabilities. The main activities included capacity building, policy development, CBR, promotion of human rights, de-institutionalisation, social inclusion and improving the collection of data.

The EU ratified the UNCRPD in December 2010. Its strategy asks member states to:

... promote the rights of people with disabilities in their external action, including EU enlargement, neighbourhood and development programmes. The Commission will work where appropriate within a broader framework of non-discrimination to highlight disability as a human rights issue in the EU's external action; raise awareness of the UN Convention and the needs of people with disabilities, including accessibility, in the area of emergency and humanitarian aid; consolidate the network of disability correspondents, increasing awareness of disability issues in EU delegations; ensure that candidate and potential candidate countries make progress in promoting the rights of people with disabilities and ensure that the financial instruments for pre-accession assistance are used to improve their situation.

EU action will support and complement national initiatives to address disability issues in dialogues with non-member countries, and where appropriate include disability and the implementation of the UN Convention taking into account the Accra commitments on aid effectiveness. It will foster agreement and commitment on disability issues in international fora (UN, Council of Europe, OECD). ${ }^{119}$

In 2010, the EU adopted a Disability Strategy 2010-2020 to develop a barrier-free Europe - inclusive education and training is one of eight key areas. 


\section{Inclusion International}

Inclusion International (II) is a worldwide federation of parent-driven associations advocating for children and adults with intellectual disabilities. It has worked with local and national associations in many countries. The associations explore the role they can play in influencing policy where education authorities have not yet addressed the issue of inclusive education. In Inclusion International's view the UNCRPD promotes the goal of full inclusion and guarantees the right of every child to attend regular school with the supports they require. Inclusive education requires that schools are supported to welcome all students with adaptations made for all special needs. Inclusion International believes that effective inclusive education requires the regular school system to respect the principles of non-discrimination; accessibility; accommodation to specific needs through flexible and alternative approaches to learning and teaching; equality of standards; participation; support for meeting disability-related needs; and relevance to preparation for the labour market. ${ }^{120}$

In 2009, Inclusion International published a study of the global reality of inclusive education, Better Education for All. It draws on 75 country profiles, 270 personal stories, 119 focus groups with family members, self-advocates, government officials and teachers, and a survey of 750 teachers and 400 parents. The study evaluates progress towards inclusive education, mainly for those with intellectual impairments, and suggests strategies to make this a reality utilising the UNCRPD. ${ }^{121}$

The main findings were that, despite pockets of good practice, the global experience 15 years after the adoption of the Salamanca Statement is not encouraging. This is measured against the six goals of Education for All and concludes:

Our analysis makes clear that EFA is not yet making the difference it needs to make for people with intellectual disabilities. In fact, Education for All is failing us. Early Childhood Care and Education (ECCE), Goal 1 of EFA, is well recognised as essential to healthy childhood development and a good 'head start' for primary school, especially for children with disabilities. Yet the data gathered for this study suggests that programmes are inaccessible, young children with intellectual disabilities are not welcome, and those that do access some programming are not getting what they need to prepare them for primary school. A 'medical model' predominates, which often labels children with intellectual disabilities, posing one more barrier to an expectation that they would benefit from further education. Lack of programmes, and incoherent policy and programming all contribute to an ECCE system that leaves children and their families without the supports and interventions to be 'school ready.'

A number of barriers prevent children with intellectual disabilities from getting access to primary education, Goal 2 of EFA. Separate responsibility for children with disabilities, whether in social welfare departments of government or special education departments in schools and school districts, is a major barrier to children with disabilities accessing regular primary school. Add to this the fact that many children with intellectual disabilities are not registered at birth and so cannot enrol in school, lack of in-school supports and financial costs of access imposed on parents. The right to education is being systematically denied to this group in the majority of cases. Barriers to ECCE and primary schooling mean that children with intellectual disabilities who do enrol often do not complete programmes. This means an even smaller enrolment in secondary education and hardly any enrolment in postsecondary education or vocational training that give essential life and vocational skills - Goal 3 of EFA. Those who are lucky enough to go on to post-secondary 


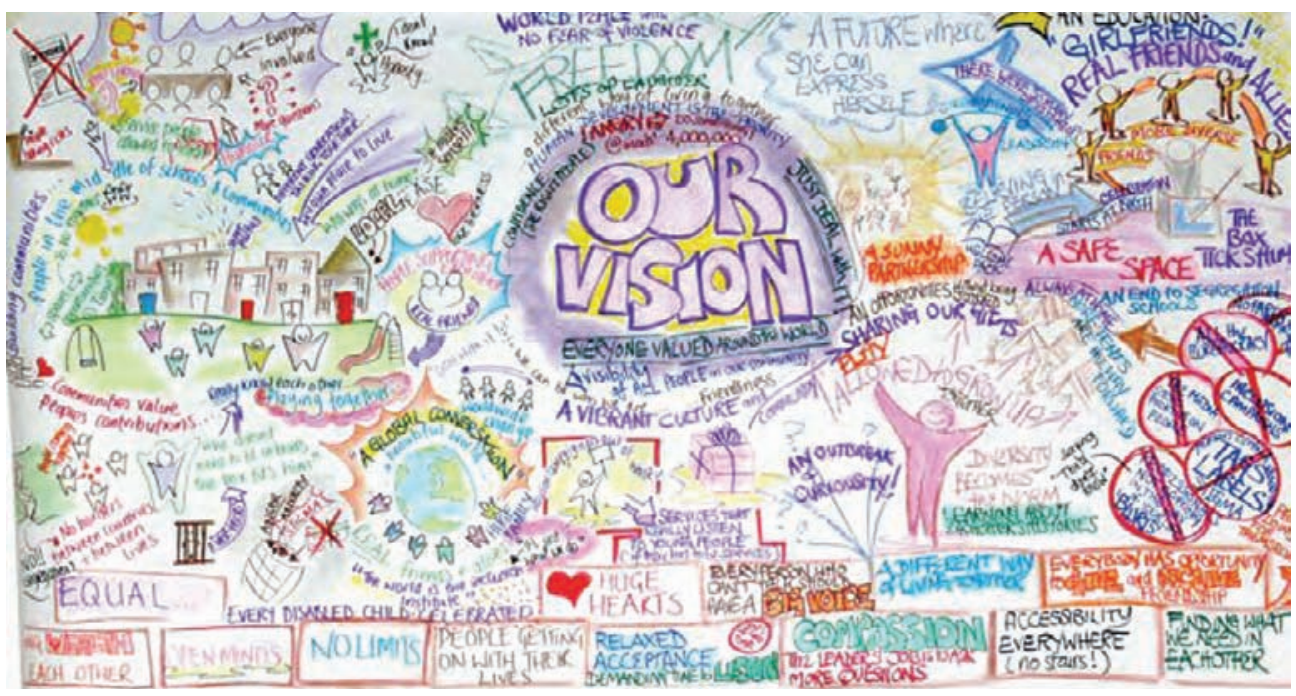

education usually find inflexible curriculum and lack of support for successful outcomes and completion. Many self-advocates shared stories of simply giving up, or finding themselves in sheltered workshops, that were presented as 'vocational training.' Or they find themselves completely isolated in their community.

Adult education - Goal 4 of EFA - is just as elusive for people with intellectual disabilities. With hugely disproportionate rates of illiteracy, self-advocates face limited access to the few programs available in most communities, and expectations that they are unlikely to benefit.

The barriers for girls and women with intellectual disabilities to ECCE, primary, secondary and adult education, are even greater. Their exclusion from education at all levels is one of the main factors that makes women and girls particularly vulnerable to poverty, ill-health and abuse. Goal 5 of EFA - gender equity in education - remains a distant hope for girls and women with intellectual disabilities.

With a few exceptions, quality education - Goal 6 of EFA - is simply not available for children, youth and adults with intellectual disabilities. We define quality in this study as having four main dimensions - positive and enabling attitudes for inclusion, supportive and trained teachers, adaptable curriculum and assessment, and accessible and supportive schools. The 'supply' of all these educational components is foundational to a good education. Our study suggests that none of these factors are in place anywhere near the extent needed, and the consequence is entrenched educational exclusion.

With such a comprehensive set of barriers to educational equality and inclusion, how do we develop and implement a global agenda where Education for 'All' means all children, youth and adults with intellectual disabilities? First we need a shared direction. Based on the findings from our global study, Table 5.2 provides such a direction. It shows how the EFA goals would have to be defined and measured to be inclusive of children, youth and adults with intellectual and other disabilities.

The Inclusion International study examines examples of good inclusive education at the micro level (individual, classroom); the mezzo level (school, community, education system; and the macro level (law, policy and cultural).

A categorisation that came out of the three North-South dialogues on inclusive education convened by India's National Resource Centre for Inclusion between 2001 and 2005 also used these three levels to reflect on the process of systemic change for inclusive education with advocates, educators, researchers, and policy-makers. Three volumes of papers from these dialogues provide a wealth of examples. ${ }^{122}$ 
Table 5.2. How the Education for All goals can promote inclusive education

\begin{tabular}{|c|c|}
\hline Education for All goals & An inclusive approach to meeting the goals \\
\hline $\begin{array}{l}\text { 1. Expanding and improving comprehensive early childhood } \\
\text { care and education, especially for the most vulnerable and } \\
\text { disadvantaged children. }\end{array}$ & $\begin{array}{l}\text { Early childhood care and education is inclusive of } \\
\text { and accessible to children with disabilities, and } \\
\text { provides transitions to inclusive primary education. }\end{array}$ \\
\hline $\begin{array}{l}\text { 2. Ensuring that by } 2015 \text { all children, particularly girls, } \\
\text { children in difficult circumstances and those belonging to } \\
\text { ethnic minorities, have access to, and complete, free and } \\
\text { compulsory primary education of good quality. }\end{array}$ & $\begin{array}{l}\text { Children with disabilities are welcomed in regular schools } \\
\text { and classrooms in the public education system, and have } \\
\text { the supports needed to complete free and compulsory } \\
\text { primary education. }\end{array}$ \\
\hline $\begin{array}{l}\text { 3. Ensuring that the learning needs of all young people } \\
\text { and adults are met through equitable access to } \\
\text { appropriate learning and life-skills programmes. }\end{array}$ & $\begin{array}{l}\text { Young people and adults with disabilities have the } \\
\text { disability-related supports needed to participate in a } \\
\text { full range of inclusive secondary, post-secondary, adult, } \\
\text { literacy, vocational and continuing education programmes. }\end{array}$ \\
\hline $\begin{array}{l}\text { 4. Achieving a } 50 \text { per cent improvement in levels of adult } \\
\text { literacy by } 2015 \text {, especially for women, and equitable } \\
\text { access to basic and continuing education for all adults. }\end{array}$ & $\begin{array}{l}\text { Adults with disabilities have full access and needed } \\
\text { support to literacy programmes to achieve literacy on } \\
\text { an equal basis with others. }\end{array}$ \\
\hline $\begin{array}{l}\text { 5. Eliminating gender disparities in primary and secondary } \\
\text { education by } 2005 \text {, and achieving gender equality in education } \\
\text { by } 2015 \text {, with a focus on ensuring girls' full and equal access } \\
\text { to and achievement in basic education of good quality. }\end{array}$ & $\begin{array}{l}\text { Girls and women with disabilities have equal access - } \\
\text { to age appropriate and inclusive education from ECCE } \\
\text { to primary, secondary, post-secondary and adult } \\
\text { education. }\end{array}$ \\
\hline $\begin{array}{l}\text { 6. Improving all aspects of the quality of education and } \\
\text { ensuring excellence of all so that recognised and measurable } \\
\text { learning outcomes are achieved by all, especially in literacy, } \\
\text { numeracy and essential life skills. }\end{array}$ & $\begin{array}{l}\text { Quality inclusive education is enabled in ECCE, primary, } \\
\text { secondary, post-secondary and adult education through: } \\
\text { - positive attitudes of educators and community } \\
\text { - trained and supported teachers } \\
\text { - accessible schools and an inclusive education } \\
\text { infrastructure } \\
\text { - individualised, differentiated and disability-positive } \\
\text { curriculum for all students } \\
\text { - learner-centred assessment strategies valued equally } \\
\text { with standardised assessments. }\end{array}$ \\
\hline
\end{tabular}

Inclusion International points to three main findings:

1. Inclusive education works, but success is ad hoc: only a minority of children with intellectual impairments are included in regular education with the support they need.

2. There is a growing commitment to build upon: 60 per cent of 75 countries had legislation, 95 per cent of parents wanted it. Teachers and international donors increasingly support inclusive education.

3. Systematic barriers - why commitments fail to transform into policy and practice. The study suggests eight barriers: (i) a political vacuum of leadership and accountability; (ii) invisible children, who are not identified and not included; (iii) unsupported families; (iv) unsupported teachers; (v) little 'knowledge networking' and 'knowledge mobilisation'; (vi) an unaware public; (vii) supplyside exclusion - physical barriers and lack of school-based supports; (viii) systematic failure of the state.

Inclusion International held an international conference to review inclusive education 15 years after Salamanca in November 2009. It issued the following declaration:

We the undersigned participants in the Global Conference on Inclusive Education - Confronting the Gap: Rights, Rhetoric, Reality? Return to Salamanca, held at the 
University of Salamanca, Salamanca, Spain (21-23 October 2009):

1. Reaffirm the commitment of the Salamanca Statement (1994) and the Conclusions and Recommendations from the 48th Session of the International Conference on Education (ICE) and commit to develop an inclusive education system in every country of the world. We welcome the UN Convention on the Rights of Persons with Disabilities (UNCRPD) and in particular Article 24 which gives new impetus to the Human Right of inclusive education for all people with disabilities.

2. We understand inclusive education to be a process where mainstream schools and early years settings are transformed so that all children/students are supported to meet their academic and social potential and which involves removing barriers in environment, communication, curriculum, teaching, socialisation and assessment at all levels.

3. We call on all Governments to ratify the UNCRPD and to develop and implement concrete plans to ensure the development of inclusive education for all. In addition we call on international agencies such as UNESCO, UNICEF and the World Bank to increase and prioritise their efforts to support the development of inclusive education.

4. We commit ourselves to form an alliance to transform global efforts to achieve Education for All creating better education for all through the development of inclusive education and hereby launch INITIATIVE 24 as a vehicle to achieve our goal. ${ }^{123}$

Inclusion International went on to provide a useful framework for how to use all parts of the UNCRPD to bring about an inclusive education system, aimed particularly at governments, donors and Education for All.

Previous work by Inclusion International showed that parent groups can have an impact when they:

- Identify schools that are willing to move forward and are interested in staff development;

- Establish links and partnerships with ministries of education and local authorities;

- Organise information seminars and training workshops to introduce new thinking and practices;

- Facilitate school-based staff development, monitoring, support, evaluation and dissemination;

- Engage with educational authorities on policy development in support of inclusive education.

\section{International Disability and Development Consortium}

The International Disability and Development Consortium (IDDC) and its members aim to promote inclusive development. It has 23 full members, all NGOs involved in and committed to inclusive development, committed to a human rights approach. Most are international NGOs, with a few disabled-led organisations. They include Leonard Cheshire Disability (LCD), Sightsavers, World Vision, Save the Children UK, ADD International, Atlas Alliance, Handicap International and Voluntary Service 
Overseas (VSO). A number of these international NGOs are based in the UK; they advocate for inclusive education for disabled children and support projects around the world. Some of these NGOs are good at involving the local leaders of the disabled people's movement in their projects. ${ }^{124}$

\section{Leonard Cheshire Disability}

Leonard Cheshire Disability is a London based international NGO that runs homes for disabled people in many Commonwealth countries. In recent years it has become an advocate of disabled people's rights and inclusive education. It has developed successful inclusive education projects in Kenya (Box 7.10), Bangladesh and Pakistan, and projects in Kenya, Botswana, Zimbabwe, Sierra Leone, Liberia, Uganda, South Sudan, Zambia and the Philippines, some of whose governments are now interested in scaling up. At an international level, LCD is active in the IDDC and at the UN in promoting inclusive education. Its project, Young Voices (Box 1.2), has produced some powerful messages to decision-makers from young disabled people. LCD has also developed a research wing based at University College, London and has co-hosted a number of international conferences on inclusive development (http:// www.lcint.org/?lid=5060).

\section{Making It Work}

Making It Work (MIW), supported by Handicap International, has a strategy of fully involving disabled people and their organisations in projects, linking a number of countries in different regions of the world to implement aspects of the UNCRPD. The 'Making it Work' Initiative is a global multi-stakeholder project to promote effective implementation of the UNCRPD. ${ }^{125}$ The 'Rights in Action' initiative is implemented as part of a broader regional project, Droit, Egalité, Citoyenneté, Solidarité, Inclusion des Personnes Handicapées (DECISIPH), which addresses the issues of rights, equality, citizenship, solidarity and inclusion of disabled people across six countries in West Africa: Burkina Faso, Mali, Niger, Senegal, Sierra Leone and Togo. DECISIPH is a fiveyear programme, started by Handicap International in 2008, and implemented in partnership with the Secretariat of the African Decade of People with Disabilities (SADPD); national DPO federations; national and local DPOs; and public institutions responsible for disability issues. SADPD (www.africandecade.org) has a vision of an African continent where disabled people enjoy their human rights. It is a DPO.

The primary objective of the 'Rights in Action' initiative is to promote practical, evidence-based recommendations on how to achieve inclusive local governance in

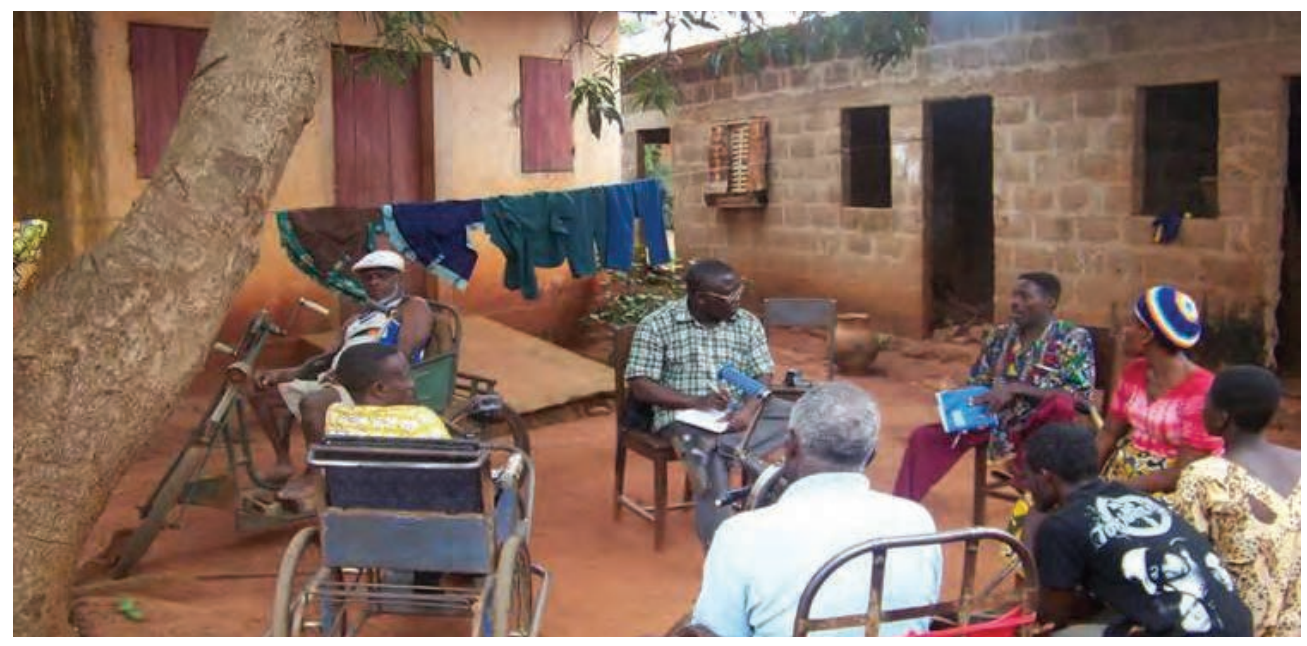

Leonard Cheshire Disability

Disabled people's organisation meeting.

CREDIT: HANDICAP INTERNATIONAL 
Figure 5.1. The Rights in Action initiative

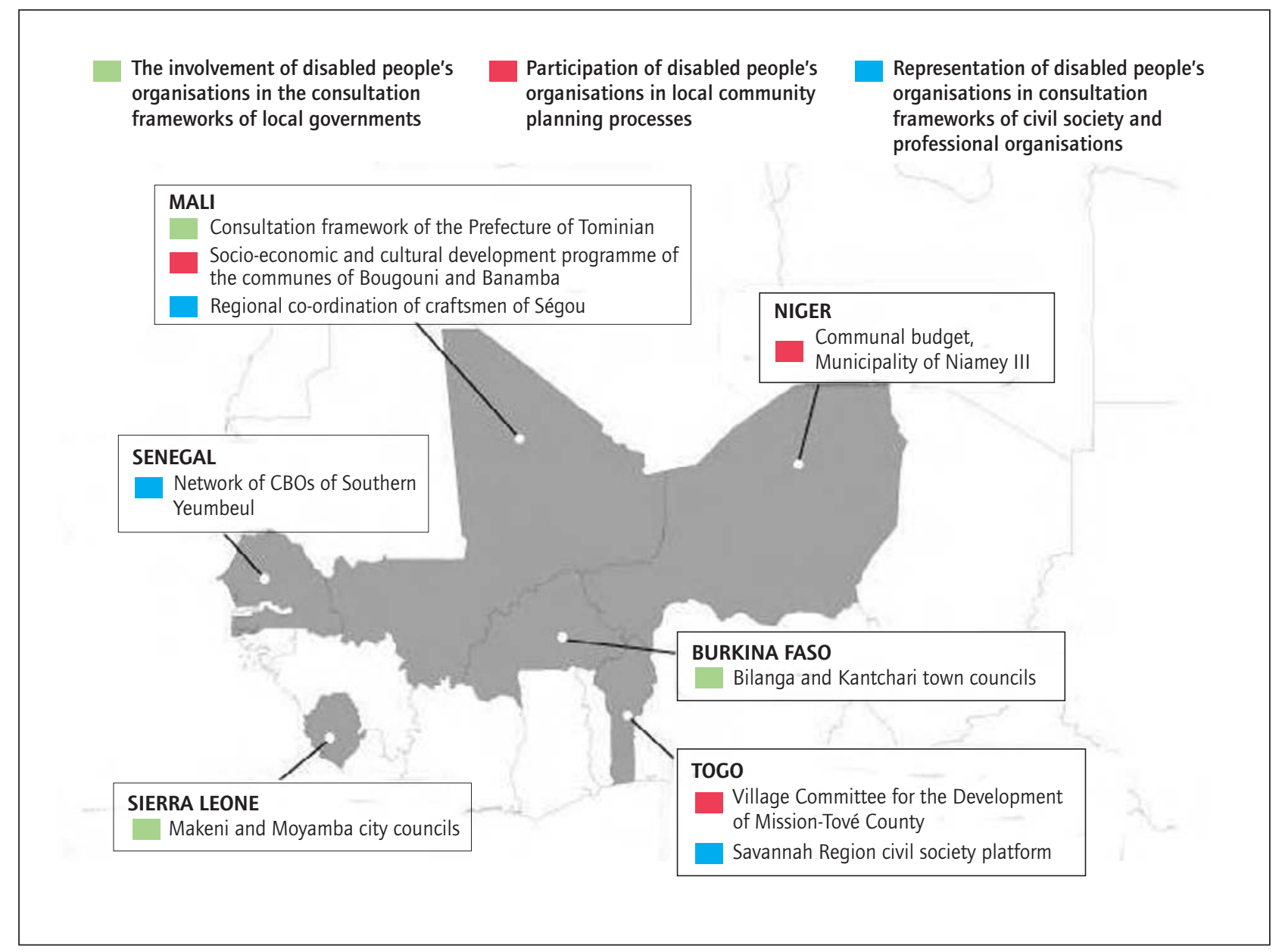

West Africa, so that disabled people can play an active role in shaping the local policies and services that impact directly on their lives. Underpinning this objective is the goal of promoting effective implementation of the UNCRPD at all levels across West Africa. ${ }^{126}$ The Framework which supports DPOs to work with other stakeholders is an empowering one for disabled people, rather than the disempowerment that other international NGOs promote unintentionally, as they follow the logic of promoting their particular organisation, sometimes at the expense of achieving the longer term objectives of implementation of the UNCRPD. Making It Work brings many of these international NGOs together with DPOs.

An example of how the framework devised by Making It Work has been applied in West Africa is in the San municipality, Mali. ${ }^{127}$ Good practice was made possible by constructive dialogue and the creation of a disability focal point inside the local education administration, demonstrating that the concerns of disabled people were being taken into account by policy-makers at the local level.

\section{Save the Children}

Save the Children has been a champion of inclusive education for many years and works as an international NGO in more than 100 countries. It states on its website:

Education has the power to transform children's lives, now and for generations to come. We're helping millions of children go to school. Education is many children's 
route out of poverty. It gives them a chance to gain valuable knowledge and skills, and to improve their lives. And it means when they grow up, their children will have a much better chance of surviving and thriving. But millions of children today never see the inside of a classroom. Many others drop out, often because their class is overcrowded and the teachers poorly trained. That's why we're helping millions of children go to school for the first time, and improving the quality of the education on offer. ${ }^{128}$

An early example of Save the Children's commitment was support for the development of inclusive education in Vietnam, ${ }^{129}$ giving assistance with training, communitybased rehabilitation and resource development. In 2006 Save the Children UK (SCUK) produced a comprehensive policy statement on inclusive education (Box 5.1). ${ }^{130}$

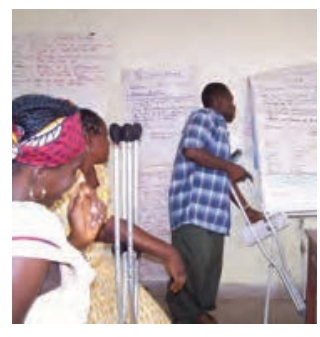

Disabled people's organisation planning session.

CREDIT: HANDICAP INTERNATIONAL

\section{Box 5.1 Save the Children UK's ten principles}

1. Every child has the right to quality education: all children should have equal opportunity to access education.

2. All children can learn and benefit from education.

3. No child should be excluded from, or discriminated against within, education on the grounds of race, colour, sex, language, age, class or caste, religion, political or other opinion, national, ethnic or social origin, poverty, disability, birth, or any other status.

4. Inclusive education promotes changes throughout the education system and with communities, to ensure that the education system adapts to the child, rather than expecting the child to adapt to the system.

5. Children's views must be listened to and taken seriously as active participants in school and in their own learning.

6. Individual differences between children are a source of richness and diversity, and not a problem.

7. The diversity of needs and patterns of development of children should be addressed through a wide and flexible range of responses.

8. Regular schools with an inclusive orientation are the most effective means of combating discrimination, building an inclusive society and achieving education for all.

9. Simply placing excluded children within a mainstream setting does not of itself achieve inclusion: reform of mainstream education is usually necessary to ensure that the needs of all children can be met.

10. All aspects of education, including the curriculum, teaching methods, school culture and environments, present opportunities for promoting inclusion.

Miles (2002) recounts good practice in Save the Children projects in Zambia, Morocco, Nepal, Lesotho, Lao-PDR, Mali, India, Vietnam, UK, Papua New Guinea, Tajikistan and China. A Save the Children report, Making Schools Inclusive, records some of the many projects the organisation has been involved in around the world 


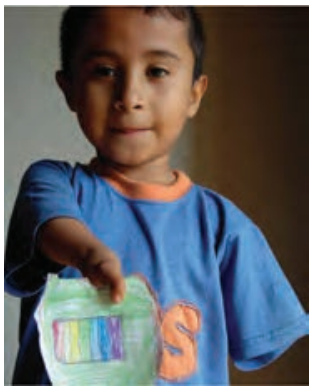

'See me, hear me'. Dan Alder, Save the CHILDREN

and draws out lessons learned (Save the Children, 2008). It is a useful document with many hands-on examples.

In 2009, Save the Children commissioned Gerison Lansdown to produce a guide to using the UNCRPD. Lansdown is an international consultant on disabled children's rights and was largely responsible for getting Article 7 into the Convention. She has drawn on her years of work on the Convention on the Rights of the Child to produce a useful synthesis of the See Me, Hear Me guide, which is informed by workshops with disabled children and many examples from around the world. Lansdown links Article 24 with Articles 28, 29 and 23 of the CRC (Box 5.2). ${ }^{131}$

\section{Box 5.2 Advocacy tips on the right to education from See Me,} Hear Me

- Advocate for the introduction of legislation to ensure the equal right of every child to an education, without discrimination of any form, on any grounds.

- Advocate for an end to segregated 'special' education and for the right of all children to a properly supported inclusive education in the general system.

- Press the government to provide accurate data on the numbers of children with disabilities in and out of school.

- Advocate for strategies to achieve the Education for All goals and MDGs to make explicit provisions to realise the right of children with disabilities to education.

- Develop and promote models of good practice in inclusion and participation - how it can be done, what resources and facilities are needed, the impact on children and the educational outcomes.

- Develop and provide training resources for teachers on working in inclusive environments. Advocate for this training to be incorporated into pre- and in-service training for all teachers.

- Support groups of children with disabilities to become advocates for the right to education. Promote opportunities for them to speak to community groups, school governing bodies, media and government representatives.

Save the Children Norway supported the development of inclusive education in Laos from 1993 to 2009. In evaluating this project, Grimes (2010) points out how it began as an initiative in one mainstream school in Vientiane, aiming to provide access to the mainstream for disabled children. By 2009 it had expanded to 539 schools, including three special schools in 141 districts, covering each of the 17 provinces, ensuring that over 3,000 disabled children were educated alongside their peers.

The five-point star of child-centred pedagogy was used in most schools, but in none were all five points in regular use. The five points are:

- A range of different activities should be taking place during the lesson;

- Use of visual, tactile and audio resources to support learning;

- Student groupings using more able students to support least able students; 
- A questioning style inviting responses from the pupils and groups discussing together;

- Relevance to real life and learners experience.

In evaluating inclusive education, a variant of the Index for Inclusion was drawn up. This demonstrated that for those with more significant impairments the specifics of support were not available in Laos. Schools had been good at including children with mild to moderate impairments, but this was leading to children with severe learning difficulty, autism and cerebral palsy not going to school. The authors' suggestion is that the Ministry of Education should train specialist advisory teachers in each province to support visual impairment, hearing impairment, communication impairment, learning difficulty and physical impairment. Their job would be to support schools in identifying children's support needs and developing effective interventions and resources, and to provide teacher training. In the longer term there needs to be a resource centre in every district. The authors point out that this strategy would be more cost-effective than setting up special schools, as has occurred in the countries neighbouring Laos.

Recently, Save the Children and Handicap International produced a report on sexual violence against disabled children, drawing on a world literature review and fieldwork in four African countries: Burundi, Madagascar, Mozambique and Tanzania. Based on interviews with 89 disabled adults and 150 carers and professionals, the report paints a bleak picture of abuse and vulnerability of disabled children. Articles 7, 15,16 and 17 of the UNCRPD place legal obligations on states parties to eradicate such treatment, but much awareness raising (Article 8 ) will be necessary to ensure that this is done. ${ }^{132}$

\section{UNESCO}

UNESCO is among the foremost proponents of inclusion and has produced some indispensable guides for teachers and administrators (see Chapters 2, 4 and 8).

\section{UNICEF}

UNICEF virtually ignored disabled children for more than ten years, but is now making the promotion of disability rights and inclusive education a priority. It states:

Children with disabilities ... have the same basic right to education as everyone else. Promoting quality education to children with special learning needs and disabilities will also empower them, and help them achieve their full potential. We urgently need to correct the wrongs of the past and equip schools, teachers and learners to make their rights become a reality. Expanding our Child Friendly Schools modules and tools will enable us to do just that. ${ }^{133}$

A report published by UNICEF in 2007 concluded:

Children with disabilities and their families constantly experience barriers to the enjoyment of their basic human rights and to their inclusion in society. Their abilities are overlooked, their capacities are underestimated and their needs are given low priority. Yet, the barriers they face are more frequently as a result of the environment in which they live than as a result of their impairment.

While the situation for these children is changing for the better, there are still severe gaps. On the positive side, there has been a gathering global momentum 
over the past two decades, originating with persons with disabilities and increasingly supported by civil society and governments. In many countries, small, local groups have joined forces to create regional or national organisations that have lobbied for reform and changes to legislation. As a result, one by one the barriers to the participation of persons with disabilities as full members of their communities are starting to fall.

Progress has varied, however, both between and within countries. Many countries have not enacted protective legislation at all, resulting in a continued violation of the rights of persons with disabilities.

UNICEF, 2007

In a helpful synthesis of the UNCRPD and CRC, the report stresses the following as key next steps:

1. Undertake a comprehensive review of all legislation in order to ensure that consideration is given to the inclusion of children with disabilities. Prohibition of discrimination on grounds of disability should be included in all legislation.

2. Provide for effective remedies in cases of violations of the rights of children with disabilities and ensure that these are accessible to all children, families and carers.

3. Develop a national plan for action framed by the relevant provisions of the CRC and UNCRPD, together with the Standard Rules. Action plans should specify measurable targets, evaluation indicators and timetables and should be monitored accordingly.

4. Create a focal point for disability in each relevant ministry, as well as a high level multi-sectoral co-ordinating committee, with members drawn from all relevant ministries and from organisations of persons with disabilities. This committee should be empowered to be proactive in initiating proposals and policies.

5. Develop independent monitoring mechanisms, such as an ombudsperson or children's commissioner, and ensure that children and families are fully supported in gaining access to such mechanisms.

6. Create an earmarked budget to ensure that funds are targeted at agreed areas of need, such as financial support for families, income maintenance, professional development and the promotion of access to buildings and services.

7. Conduct awareness-raising and educational campaigns targeting the public at large, as well as specific groups of professionals.

8. Have particular regard to the additional vulnerability of girls and women to discrimination.

UNICEF, 2007

Following the review of the EFA Flagship, 'The Right to Education for Persons with Disabilities: Towards Inclusion', held in Paris in May 2011, it has been suggested that UNICEF will now lead on co-ordinating a network of partners around the world to take forward the Flagship. This results from a lack of progress with UNESCO's generic approach to inclusive education; the withdrawal of the Finnish Government as lead funder; and the need to co-ordinate and not duplicate efforts by INGOS, DPOs and donors. 


\section{World Bank}

From 1995 to 2005 under the leadership of its President, James Wolfensohn, the World Bank transformed itself. There was a change of emphasis from what could be done to what should be done and recognition that without the inclusion of the poor, including disabled people, nothing would change. With dwindling resources, the World Bank became more ambitious in wishing to tackle issues of social justice and not just growth. ${ }^{134}$

The World Bank's approach to disability focuses on inclusive development and human capital development as necessary to achieve the MDGs. In operational terms, it finances disability-related projects (e.g. in the fields of education, health, infrastructure and employment). It capitalises on knowledge by supporting surveys and research, and documenting good practice. In addition, the Bank supports accessible infrastructure in relevant projects.

In 2002, together with development partners, the World Bank launched the Education for All Fast Track Initiative. The FTI is a global partnership to help lowincome countries meet the education MDGs and the EFA goal that all children should complete primary education by 2015 . It is a platform for collaboration at the global and country levels. Through the FII compact, developing countries commit to designing and implementing sound education plans, while donor partners commit to harmonising additional support around these plans. Funding is channelled through existing bilateral and multilateral channels and also through the FTI Catalytic Fund (CF), which supports countries with insufficient resources to implement their sector plans. ${ }^{135}$

The Fast Track Initiative was renamed the Global Partnership for Education, with a launch at the UN General Assembly on 21 September 2011. This change builds on the initiative's successes over the last ten years and is part of a redoubled commitment to making sure all children in low-income countries have access to quality education and opportunities to learn. ${ }^{136}$

\section{How the Global Partnership for Education works}

The Global Partnership for Education is built on the principles of country ownership and local-level empowerment, as well as mutual accountability and donor harmonisation rooted in the Monterrey Consensus and Paris Declaration principles. Its vision encompasses:

1. Country preparation of a sound education sector plan addressing policy, capacity, data and funding gaps, as well as a poverty reduction strategy paper (PRSP);

2. Endorsement of the plan by the country's local donor group, to signal to bilateral and multilateral financiers that the plan is investment-ready;

3. Alignment and harmonisation of donor support around this country-owned, investment-ready plan.

The World Bank plays a significant role in the partnership: as well as launching the partnership, in collaboration with other donors, it hosts the Global Partnership for Education Secretariat and serves as trustee for Global Partnership for Education trust funds, including the new Education for All Fund. The Bank is also the supervising entity for most allocations provided to Global Partnership for Education countries. Collaborating with developing country and donor country partners at country and global levels to realise the promise of the Partnership is a high priority for the Bank.

The Partnership is much needed because it: 
- Supports the Bank's overall objectives for education, which are a vital contribution to economic and human development and poverty reduction;

- Helps countries address the large gaps they face in meeting Millennium Development Goal 2 on education in the areas of policy, capacity, data, finance;

- Helps countries accelerate progress, which requires more effective aid and more external funding;

- Assures improved efficiency and lower transaction costs for donor assistance because donors come together around a single country plan rather than engage in fragmented efforts - this is especially important in the context of substantial donor interest in primary education;

- Helps to extend the Bank's reach and leverage in support of education through the partnership;

- Recognises that progress must be country-driven - more money at the global level alone is not enough.

The World Bank's involvement is essential because it:

- Has historically been the largest external financier in education and has a strong presence in most low-income countries' education sectors;

- Brings unique strengths to the table that can benefit recipient countries and strengthen the effectiveness of aid;

- Can use its convening power to take forward the Paris Declaration agenda of donor harmonisation and alignment around each country's own education sector plan.

In April 2009, the UNCRPD Secretariat, ${ }^{137}$ in collaboration with the World Health Organization, organised the Expert Group Meeting on Mainstreaming Disability in MDG Policies, Processes and Mechanisms: Development for All. ${ }^{138}$ The meeting reviewed existing policy frameworks, resources and tools, together with mechanisms for mainstreaming disability in MDG processes, and made policy recommendations. Including a disability perspective in MDGs would also serve as benchmarks to implement a number of the specific substantive provisions in the CRPD. For example, CRPD Article 24 would be bolstered by including disability as a target under MDG 2 on universal primary education. Empirical evidence from across the world indicates that disabled children tend to have lower enrolment rates than children without disabilities. therefore, achieving MDG 2 is not possible as long as disabled children are not specifically targeted in an effort to reach universal primary education. The importance of formulating development policies and programmes in accordance with agreed international commitments, including on disability, was acknowledged in the 2008 Accra Agenda for Action. ${ }^{139}$

The review examined the policies of major multilateral and bilateral agencies on the inclusion of disability in development aid. It also provided, whenever possible, examples of their programmes. The review did not assess the merits or impact of any of the policies or practices presented. It provided a preliminary mapping of existing policies and practices to present a summary overview of developments and emerging trends in an attempt to include disability-related issues in development aid.

The review identified and described the programmes of the organisations that support the inclusion of disability in their development programmes and funding. The organisations are: 
UN Inter-Agency Support Group on the Convention on the Rights of Persons with

Disabilities

CRPD Secretariat

United Nations Department of Economic and Social Affairs

Office of the United Nations High Commissioner for Human Rights

United Nations Development Programme

Food and Agricultural Organization

International Labour Organization

UNICEF

UNESCO

United Nations Population Fund

UN High Commissioner for Refugees

UN Human Settlements Programme

UN Mine Action Service

UN Industrial Development Organization

World Health Organization

World Intellectual Property Organization

Global Initiative for Inclusive Information and Communication Technologies

World Bank

\section{Regional organisations and structures}

UN Regional Commissions and Decades

Council of Europe

European Union

Inter-American Development Bank

\section{Bilateral development agencies}

Australian Agency for International Development (AusAID)

Austrian Development Agency

Canadian International Development Agency (CIDA)

Department of Development Policy, Ministry for Foreign Affairs (Finland)

Gesellschaft fur Technische Zusammenarbeit (Germany)

Irish Aid

Direzione Generale per la Cooperazione allo Sviluppo (DGCS) (Italy)

Japan International Cooperation Agency (JICA)

New Zealand International Aid and Development Agency (NZAID)

Norwegian Agency for Development Cooperation (NORAD)

Swedish International Development Cooperation Agency (SIDA)

UK Department for International Development (DFID)

United States Agency for International Development (USAID)

\section{World Health Organization}

In 2011 WHO and the World Bank produced the World Report on Disability, which suggests how all stakeholders, including governments, civil society organisations and disabled people's organisations, can create enabling environments, develop rehabilitation and support services, ensure adequate social protection, create inclusive policies and programmes, and enforce new and existing standards and legislation, to the benefit of disabled people and the wider community. Disabled people should be central to these endeavours. The World Report states: 
Our driving vision is of an inclusive world in which we are all able to live a life of health, comfort, and dignity. We invite you to use the evidence in this report to help this vision become a reality. ${ }^{140}$

JICA has made funds available for countries to submit disability inclusion projects for World Bank funding. The President of the World Bank has taken note of the World Report and asked for a briefing about mainstreaming disability. The visibility of the Report will open a window, however briefly, where good things can be achieved. ${ }^{141}$

\section{World Vision}

World Vision is a Christian relief, development and advocacy organisation dedicated to working with children, families and communities to overcome poverty and injustice. It serves all people regardless of religion, race, ethnicity or gender. Financial support is received from the UK Government, the EU, charitable trusts, corporate supporters and more than 100,000 individuals, who sponsor children in poor communities overseas. World Vision works to change the root causes of poverty through campaigning, church partnerships, education and influencing policy-makers. In 2006/2007, concerned about the small number of disabled children in school or touched by EFA initiatives in less developed countries, World Vision commissioned Hazel Bines to look at how the Education for All FII is tackling the challenges of disability and inclusion (World Vision, 2007). Its purpose was to:

- Assess the disability responsiveness of FTI processes and education sector plans;

- Formulate recommendations to strengthen current processes, tools and partnership mechanisms; and

- Identify new opportunities through which the FTI can better address the issue of disability and education.

The study comprises:

- A review of the FTI endorsement guidelines and processes with reference to disability and inclusion, including donor assessments of plans;

- Analysis of the 28 country education sector plans endorsed by the FTI between 2002 and 2006;

- Two detailed country case studies in Cambodia and Ethiopia; and

- A review of policies and practices in other selected countries, some of which are now preparing for FTI endorsement.

The study also looks at the extent to which the FTI Education Program Development Fund (EPDF) focuses on disability and inclusion, and at donor perspectives and harmonisation in relation to disability and inclusion. It states:

In reviewing country plans, the study took as its starting point that plans should:

- Reflect international commitments to the rights of disabled children to be educated;

- Identify the number of disabled children and assess their needs;

- Have strategies on key aspects of provision, such as making school buildings accessible and the development of curriculum, teaching methods and materials to meet a diversity of needs, with appropriate management arrangements; 
- Aim to develop capacity, through scaling up provision and training programmes;

- Acknowledge the importance of parental support and community involvement;

- Include appropriate and sufficient financing;

- Address monitoring and evaluation, including improvements in student data and other information.

No country met all the above criteria. This was expected given the many other challenges countries face in improving their education services. However, a number of FTIendorsed countries, particularly those which are approaching universal primary education, do now have education sector plans which address the inclusion of disabled children. Most of these plans focus on making regular schools more inclusive, through improvements in teacher training and provision of additional learning materials and support, although some retain some special provision. Of the 28 country reports analysed, eight were from Commonwealth countries. Five - Ghana, Guyana, Kenya, Lesotho and Mozambique - made positive mention of disability and included it in their plans. Two - The Gambia and Rwanda - had some mention and Cameroon none. Even if disability is mentioned, there is still a need for measures to be implemented to change the lives of disabled children (Table 2.1). ${ }^{142}$

A few countries are setting targets for enrolment and instituting financial and other incentives to encourage schools to become more inclusive. Some link disability to other initiatives to increase equity and reach excluded children. However, in a number of countries, policies and provision for disabled children remain cursory or have not been implemented. Key gaps include:

- Lack of data on the total number of disabled children, the proportion who do not attend school and the range of provision;

- Insufficient planning across a range of measures to improve provision, respond to the diversity of learning needs and increase capacity;

- Few financial projections of costs, or use of funding mechanisms and incentives to encourage and support inclusion;

- Limited approaches to partnership with parents, communities and NGOs;

- Weak inter-ministry/sectoral/services links.

There is also insufficient clarity on policy approaches, particularly the differences between 'integration' (location of individual children in current provision) and 'inclusion' (systematic change to accommodate diversity).

However, there are some examples of promising practice at local level, many of which have been initiated by international and national NGOs, which demonstrate both the benefits and the practicalities of inclusion. In relation to FTI processes and support, the FTI is concerned with the participation of disabled children as part of its focus on universal primary completion, and its endorsement process guidelines refer to disability as one of the areas which education plans should address.

Having an explicit policy on disability is not identified as a critical aspect of education sector plans. Some country donor partner assessments evaluate whether countries' education plans address disability, but others do not. There are considerable differences between donors as to policies and levels of advocacy and support in relation to disability and education. The EPDF, which has supported a number of countries to develop plans and capacity, has not included disability as a priority. There has 
been some fostering of information exchange on policies and strategies in relation to disability and inclusion in education.

The main conclusion of the World Vision study is that:

... taking together both FTI endorsement processes and funding support, and country plans and donor assessments, the FTI Partnership could be considered as not yet being responsive enough to disability.

As pointed out in Chapter 2, this report had a direct impact on donors and international agencies in their efforts to include disabled children, but because they are starting from a generalist inclusion model, rather than the specifics required to successfully implement a social model approach, the problems identified are continuing.

All teachers do have inset training on child friendly teaching methods and most promising practice is NGO initiated. On visits to six schools designated as inclusive, the authors found children who could cope with unmodified schools such as visually impaired or post-polio impaired pupils and a reliance on peer support, but little evidence of reasonable accommodation. At national and provincial level they found some positive features, such as political commitment in Cambodia and widespread support for inclusive education, but there were a number of key concerns:

- The lack of co-ordination and no clear delineation of roles and responsibilities between NGOs and government ministries;

- Too many priorities and too few resources makes it hard to prioritise disability issues;

- A lack of data on prevalence rates of disabled children, due in part to difficulties in identifying and screening them, impacts on policy planning;

- The shortage of teachers, especially those trained to work with disabled children, and a lack of incentives and skills;

- The lack of clarity on the meaning of inclusive education, with some seeing it as the education of disabled children, while others take it to mean education for all;

- Discrimination in communities means that despite verbal support for inclusive education from teachers and school directors, many do not allow disabled children to come to school if modifications are needed;

- Widespread poverty means that many families have no access to health care or assistive devices and cannot afford to pay the informal costs associated with education. ${ }^{143}$

In 2010 World Vision produced a training pack, Travelling Together, written by Sue Coe and Lorraine Wapling and funded by DFID. ${ }^{144}$ The pack is based on exercises developed by disabled equality trainers, ${ }^{145}$ but not credited to them. It underlines one of the weaknesses of international NGOs working in the area of disability equality. Disability equality training must be led by disabled people who subscribe to the social model and see disability as a common oppression, as it relies on their life experience to inform participants. Remember 'Nothing About Us Without Us!'. 


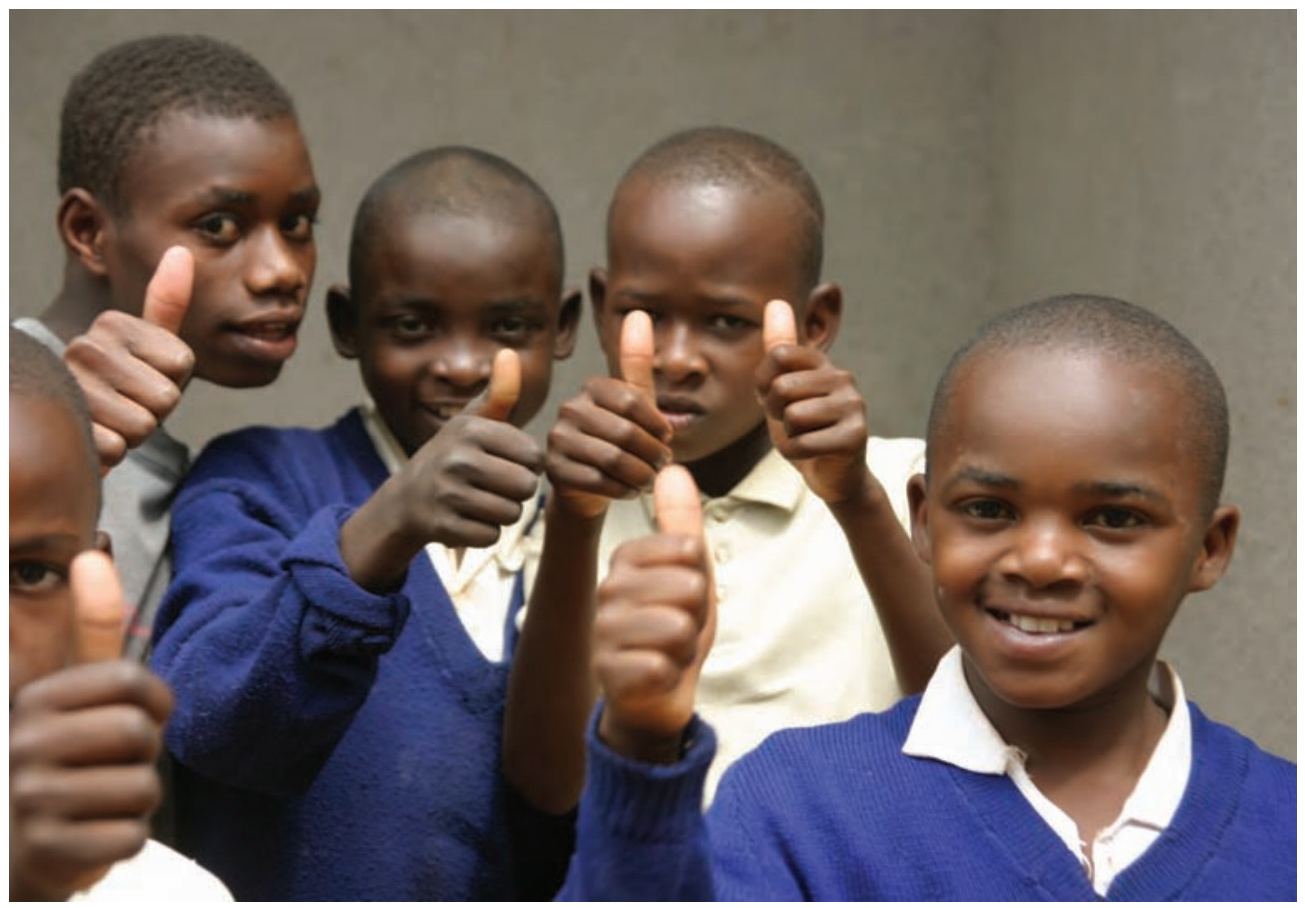

Deaf students at Maemba School, Tanzania.

CREDIT: MTAJU

\section{Conclusion}

There is no doubt that the adoption of the UNCRPD has changed international attitudes towards the systematic disadvantage and discrimination to which disabled people are subject. There is also a less strong trend among international, regional and bilateral donors towards understanding that disabled people and their representative organisations need to be involved in designing and developing the delivery of programmes aimed at disabled people. The setting up and operation of the Committee on the Rights of Persons with Disabilities, the annual Conference of States Parties and the support provided by the UN Department of Social and Economic Affairs and the Office of High Commissioner for Human Rights is slowly increasing awareness of the need to include disability issues in the work of all international agencies.

Currently, the Committee is only mandated by the UN General Council to meet twice a year for a week, although it has asked that this should be doubled. This is woefully inadequate and there is an ever lengthening queue of country reports. The guidance produced on the presentation of reports and the general discussion days are a very valuable source of information to states parties and DPOs and NGOs in the field. However, this is a very slow process and there is a risk that disability equality issues will be overtaken by other issues that are perceived as more pressing. The push for Education for All and the implementation of MDG 2, which cannot now be reached by the target date, shows signs of donor fatigue. The main focus on achieving gender equality has disguised the large percentage of disabled children who are not in school or who are not progressing with their education. Recently, a growing awareness of these issues at the UN has led to agreement on convening a High Level Meeting on Disability and Development at the 2012 UN General Assembly and a flurry of activity from UN agencies, including DESA, to gather examples of promising practice from around the world.

The strengthening of the International Disability Alliance with offices in Geneva, New York and Madrid provides a conduit for the views of the international disability movement, but it is chronically under-resourced for the huge job it has to do. The Disability Rights Fund and the Making It Work project are two small but very useful 


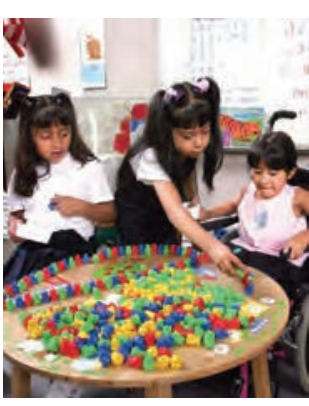

Inclusive play. CREDIT: BILL ARON

sources of funding for the development of the capacity of DPOs and for their involvement in local projects to implement the UNCRPD.

The UK, Swedish, Norwegian and Finnish Governments have made a point of including DPOs in their projects, but too often these are of limited duration and do not make a long-term improvement in the position of disabled people. In recent years, AusAid and New Zealand Aid have concentrated on supporting capacity building of DPOs and have focused on disability issues in the South Pacific countries. The ratification of the UNCRPD by the EU holds out possibilities of mainstreaming disability issues across the aid programme, especially because of the Commission's close collaboration with the European Disability Forum. The US State Department has recently taken a strong position, influenced by the appointment of Judith Heumann as an adviser on international disability rights. The Inter-American Bank has focused on inclusive education projects in Central and South America.

The role of international NGOs can be important as a catalyst for changing government practice. Subsequent chapters cite many examples of this from Handicap International, Leonard Cheshire Disability, Light of the World, Save the Children, Sightsavers, VSO and others. The main problem is how to scale these up and to get governments to prioritise the good practice learned. UNESCO and UNICEF should play an international co-ordinating role. By publicising promising practices, they can pose the right questions to countries, but as demonstrated in Chapter 2, UNESCO in particular, by adopting a very wide definition of inclusive education, often blunts the focus on disability and the rights of disabled children. Information exchange such as those provided by EENET can be invaluable, as is seen in the many examples quoted here.

Education International, representing trained teachers around the world, supports the development of inclusive education, but argues for proper professional training and remuneration and points out that an education system increasingly based on competition undermines the collaboration necessary to deliver it.

Inclusion International and to a lesser extent Disabled Peoples' International can play a valuable role as international DPOs in organising campaigns for inclusive education for disabled children and young people, and keep their issues on the international agenda.

It is to be hoped that the WHO World Report on Disability will lead to a renewal of efforts to fund attempts to tackle the huge disparities identified and put DPOs and disabled people firmly in the driving seat of initiatives for disability equality and the inclusion of disabled learners in education. The UN General Assembly's decision to hold a High Level Forum on Disability and Development in 2012 will focus attention on current barriers and gaps.

In terms of the international layer of the disability rights in education model, there is some promising practice, but much more urgently needs to be done to develop the capacity of DPOs and provide training in disability equality for all those involved in decision- making about development funding and the implementation of projects. 